\title{
SUBSEQUENT PREGNANCIES: WHO HAS THEM AND WHO WANTS THEM? OBSERVATIONS FROM AN URBAN CENTER IN SOUTHERN BRAZIL*
}

\author{
Sharon R. A. Huttly** \\ Fernando C. Barros*** \\ Cesar G. Victora ${ }^{* * *}$ \\ Cintia Lombardi*** \\ J. Patrick Vaughan****
}

HUTTLY, S. R. A. et al. Subsequent pregnancies: who has them and who wants them? Observations from an urban center in Soluthern Brazil. Rev. Saúde públ., S. Paulo, 24: 212-6, 1990

ABSTRACT: Subsequent pregnancies in mothers of a birth cohort from Pelotas, Southern Brazil, were studied in relation to maternal and socio-economic factors. Within about $31 / 2$ years of the cohort child's birth, $39 \%$ of mothers had experienced at least one further pregnancy. This proportion decreased with increasing maternal age, years of schooling and family income. A U-shaped trend was observed with respect to parity. Mothers who had delivered the cohort child by caesarean section were also less likely to have another pregnancy within that time. Logistic regression analysis showed that each of these factors remained significantly associated with further pregnancies after controlling for the remaining variables. Analysis of the first subsequent pregnancy showed that a high proportion of mothers had not wanted the pregnancy. Unwanted pregnancies were also significantly associated with older women, low educational status, higher parity and low family income.

KEYWORDS: Fertility. Parity.

\section{INTRODUCTION}

Information on consecutive pregnancies comes largely from developed countries, where extensive linkage of birth records has been made ${ }^{1,6}$. Similar data from developing countries are rare, perhaps in part due to the inherent difficulties of longitudinal studies in such settings and to incomplcte vital registration systems. It has been noted, however, that results obtained from cross-sectional surveys do not always reflect the trends found in longitudinal follow-up studies ${ }^{1}$. On the other hand, fertility histories reported by women have limited accuracy ${ }^{3}$, thus the value of prospective follow-up studies in this context cannot be underrated. We report here data from a longitudinal birth-cohort study in Southern Brazil. When the cohort children were on average 43 months of age, mothers were interviewed about their pregnancies and births subsequent to that of the cohort child. Features of these subsequent pregnancies, and whether they were wanted or not by the mother, are presented in relation to maternal factors, family income and mode of delivery.

\section{MATERIAL AND METHOD}

The longitudinal study was conducted in Pelotas (population in 1982 of 250,000 ), a relatively developed area located in the southern-most part of Brazil. Details of the study are presented elsewhere ${ }^{2,7}$. All 6,011 hospital births which occurred during 1982 to mothers resident in the urban area of Pelotas were enrolled in the study. These represented more than $99 \%$ of all births in the city in 1982 and 5,914 (98\%) were livebirths. Mothers were interviewed within 48 hours of delivery and information recorded included family income, mocie of delivery, and maternal age, education and parity.

Follow-up studies of the children were made in 1983,1984 and 1985-6 when their mean ages were 12,20 and 43 months, respectively. At the third follow-up in December 1985 to April 1986, when a city-wide census was conducted, mothers were questioned on their pregnancies subsequent to the birth of the cohort child and information was gathered for up to the first 3 of these. This includ-

\footnotetext{
* Study funded by the Overseas Development Administration, UK and the International Development Research Centre, Canada.

* Departamento de Medicina Sorial da Faculdade de Medicina da Universidade Federal de Pelotas - Caixa Postal 464 - 96001 - Pelotas, RS - Brasil. Maternal and Child Epidemiology Unit. London School of Hygiene and Tropical Medicine - Keppel St, London, WC1E 7HT, UK.

** Departamento de Medicina Social da Faculdade de Medicina da Universidade Federal de Pelotas.

**** Evaluation and Planning Centre of London School of Hygiene and Tropical Medicine, Keppel St, London, WC1E 7HT, UK.
} 


\section{TABLE 1}

Proportion of women having at least one pregnancy within 35-52 months of the birth of the cohort child in 1982, according to family income and maternal attributes collected in 1982.

\begin{tabular}{|c|c|c|c|}
\hline Variables & $\begin{array}{l}\text { No. of } \\
\text { women }\end{array}$ & $\begin{array}{l}\% \text { with } 1+ \\
\text { pregnancy }\end{array}$ & $\begin{array}{l}\text { P-value for } \\
X^{2} \text { test }\end{array}$ \\
\hline Total & 4683 & 39 & \\
\hline $\begin{array}{c}\text { Monthly Family Income (US\$) } \\
<=50 \\
51-150 \\
151+\end{array}$ & $\begin{array}{r}908 \\
2283 \\
1473\end{array}$ & $\begin{array}{l}51 \\
37 \\
34\end{array}$ & $<0.001$ \\
\hline $\begin{array}{c}<20 \\
20-24 \\
25-29 \\
30-34 \\
35+\end{array}$ & $\begin{array}{r}668 \\
1416 \\
1272 \\
821 \\
506\end{array}$ & $\begin{array}{l}53 \\
46 \\
39 \\
28 \\
18\end{array}$ & $<0.001$ \\
\hline $\begin{array}{r}\text { Education (years of schooling) } \\
0 \\
1-4 \\
5-8 \\
9+\end{array}$ & $\begin{array}{r}219 \\
1258 \\
1989 \\
1217\end{array}$ & $\begin{array}{l}47 \\
42 \\
37 \\
36\end{array}$ & $=0.001$ \\
\hline $\begin{array}{r}0 \\
1 \\
2 \\
3 \\
4+\end{array}$ & $\begin{array}{r}1814 \\
1333 \\
775 \\
325 \\
436\end{array}$ & $\begin{array}{l}46 \\
36 \\
30 \\
33 \\
37\end{array}$ & $<0.001$ \\
\hline $\begin{array}{c}\text { Type of Delivery of Cohort Child* } \\
\text { Vaginal } \\
\text { Caesarean }\end{array}$ & $\begin{array}{r}3326 \\
914\end{array}$ & $\begin{array}{l}44 \\
38\end{array}$ & $<0.001$ \\
\hline
\end{tabular}

- Exclusions: mothers with tubal ligations and no child after the cohort child (see text for details).

ed data on whether the pregnancy was wanted and on the outcome of the pregnancy. For those who had given birth, the date of birth, birthweight, breastfeeding habits and mode of delivery were recorded. Current method of contraception was also recorded.

Those women who reported that they had undergone a tubal ligation and that they had not experienced any pregnancies subsequent to the cohort child, were considered to have been sterilised at the time of the cohort child's birth. They were included in the analysis of maternal and income factors since it was considered that the decision to be sterilised was part of the decision on subsequent pregnancies. They were, however, excluded from analysis of the effect of mode of delivery on subsequent fertility as the vast majority (88\%) had undergone a caesarean section specifically in order to have a tubal ligation. By excluding these women, it was possible to obtain an estimate of the influence of mode of delivery on subsequent pregnancies, given the possibility of having one.

\section{RESULTS}

Of the original 5,914 livebirths, $4,978(84 \%)$ were traced at the follow-up in December 1985 to
April 1986, when they were aged between 35 and 52 months (mean 43 months). Two hundred and thirty five (5\%) of these children were known to have died before this time and their families were not interviewed. Children located did not differ significantly from those not found with respect to variables such as birthweight, birth order or ethnic group but those from the highest or lowest income groups were less likely to be traced. However, at least $80 \%$ of children in each income group were located 2.7 .

Data were obtained from 4,683 mothers of whom $1,820(39 \%)$ had experienced at least one pregnancy after the birth of the cohort child. No clear trend was observed in the proportion having a subsequent pregnancy according to the time elapsed since the birth of the cohort child. Of these women, $1,429(78 \%)$ had delivered one or more children by the time of the interview and 260 (14\%) had undergone at least one abortion (72\% of which were reported to have been spontaneous). The mean birth interval was 26.6 months ( $\mathrm{SD}=9.5$ months).

The proportions of women having one or more subsequent pregnancies varied according to several maternal characteristics and family income 
TABLE 2

Odds ratios for another preginancy within 35-52 months of the birth of the cohort child, according to maternal characteristics and monthly family income.

\begin{tabular}{|c|c|c|c|c|c|}
\hline \multirow{2}{*}{ Factor } & & \multicolumn{2}{|c|}{ Unadjusted } & \multicolumn{2}{|c|}{$\begin{array}{l}\text { Adjusted for } \\
\text { other factorse }\end{array}$} \\
\hline & & $O^{b}$ & $95 \% \mathrm{Cl}^{b}$ & OR & \\
\hline \multirow[t]{2}{*}{$\begin{array}{l}\text { Monthly } \\
\text { family } \\
\text { income USS }\end{array}$} & $\begin{array}{r}<=50 \\
51- \\
151+\end{array}$ & $\begin{array}{l}1.97 \\
1.13 \\
1.00\end{array}$ & $\begin{array}{l}(1.67-2.34) \\
(0.98-1.30)\end{array}$ & $\begin{array}{l}1.48 \\
0.94 \\
1.00\end{array}$ & $\begin{array}{r}(1.20-1.81) \\
(0.80-1.11)\end{array}$ \\
\hline & $x_{2}^{2}$ & 68.7 & & 29.2 & \\
\hline \multirow[t]{2}{*}{$\begin{array}{l}\text { Age } \\
\text { (years) }\end{array}$} & $\begin{array}{l}<20 \\
20- \\
25- \\
30- \\
35+\end{array}$ & $\begin{array}{l}5.24 \\
4.00 \\
3.00 \\
1.79 \\
1.00\end{array}$ & $\begin{array}{l}(3.98-6.90) \\
(3.11-5.15) \\
(2.32-3.87) \\
(1.36-2.36)\end{array}$ & $\begin{array}{l}5.73 \\
5.01 \\
3.76 \\
2.10 \\
1.00\end{array}$ & $\begin{array}{l}(4.14-7.92) \\
(3.76-6.67) \\
(2.85-4.97) \\
(1.58-2.79)\end{array}$ \\
\hline & $x_{4}^{2}$ & 236.2 & & 178.8 & \\
\hline \multirow[t]{2}{*}{$\begin{array}{l}\text { Education } \\
\text { (years of } \\
\text { schooling) }\end{array}$} & $\begin{array}{r}0 \\
1-4 \\
5-8 \\
9+\end{array}$ & $\begin{array}{l}1.51 \\
1.28 \\
1.04 \\
1.00\end{array}$ & $\begin{array}{l}(1.13-2.02) \\
(1.09-1.51) \\
(0.89-1.20)\end{array}$ & $\begin{array}{l}1.50 \\
1.07 \\
0.87 \\
1.00\end{array}$ & $\begin{array}{l}(1.07-2.10) \\
(0.88-1.31) \\
(0.73-1.03)\end{array}$ \\
\hline & $x_{3}^{2}$ & 16.4 & & 16.2 & \\
\hline \multirow[t]{2}{*}{ Parity } & $\begin{array}{r}0 \\
1 \\
2 \\
3 \\
4+\end{array}$ & $\begin{array}{l}1.00 \\
0.64 \\
0.49 \\
0.58 \\
0.69\end{array}$ & $\begin{array}{l}(0.56-0.74) \\
(0.41-0.59) \\
(0.45-0.74) \\
(0.56-0.86)\end{array}$ & $\begin{array}{l}1.00 \\
0.76 \\
0.70 \\
0.90 \\
1.40\end{array}$ & $\begin{array}{l}(0.65-0.89) \\
(0.58-0.86) \\
(0.68-1.19) \\
(1.07-1.84)\end{array}$ \\
\hline & $x_{4}^{2}$ & 79.8 & & 36.6 & \\
\hline \multirow[t]{2}{*}{$\begin{array}{l}\text { Mode of } \\
\text { deliveryc }\end{array}$} & $\begin{array}{c}\text { Vaginal } \\
\text { Caesarean }\end{array}$ & $\begin{array}{l}1.00 \\
0.77\end{array}$ & $(0.67-0.90)$ & $\begin{array}{l}1.00 \\
0.80\end{array}$ & $(0.68-0.94)$ \\
\hline & $x_{1}^{2}$ & 11.2 & & 7.8 & \\
\hline
\end{tabular}

a - Income, age, education and parity each adjusted for the others. Type of delivery adjusted for income, age, education, and parity.

b. $O R=$ odds ratio; $95 \% \mathrm{CI}=95 \%$ confldence interval

c- Exclusions: mothers with tubal ligations and no child after the cohort child (see text for details).

(Table 1). Further pregnancies were more common among those from lower income families and declined in frequency with increasing age and years of schooling. A U-shaped trend was observed with respect to parity, with mothers whose cohort child was their third being least likely to have another pregnancy. These factors are highly inter-related, so logistic regression was used to study the effect of each one while controlling for the others. Odds ratios for another pregnancy are shown in Table 2, both unadjusted and adjusted for other factors. All factors remained significantly associated with subsequent pregnancies and similar trends were observed for age, education and income. The effect of the latter variable was reduced but since income also influences the other variables its adjusted odds ratios reflect its effect over and above that mediated through those variables. A U-shaped trend persisted for parity and was even more pronounced than for the unadjusted values.
Excluding those women sterilised around the time of the cohort child's birth (see methods section), subsequent pregnancies were less common among women who had delivered the cohort child by caesarean section (Table 1), even after adjustment for income, age, education and parity (Table 2).

A large proportion of mothers stated that had not wanted their next pregnancy after the cohort child. In general, this proportion declined with increasing income and years of schooling and increased with age (Fig. $1 ; X^{2}$ test for comparison of proportions, $p<0.001$ for each of the 3 factors). The proportion of unwanted pregnancies increased with parity in each income group but particularly so in the richer groups (Fig. 2). Thus although unwanted pregnancies were more common in the lower income group for women of parity 1, this trend was reversed for women of higher parity. This yielded a statistically significant interaction $(p<0.01)$. 


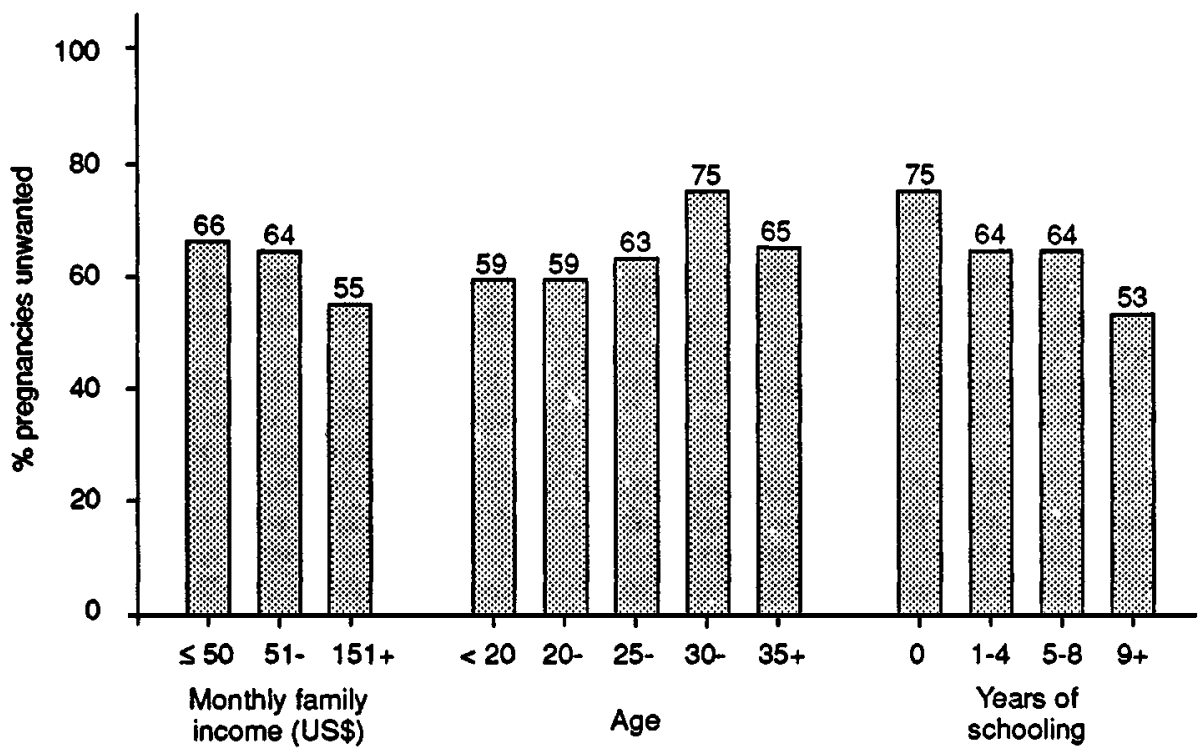

Fig. 1. Proportion of first pregnancies subsequent to a birth in 1982 that were reported by the mother as unwanted, according to family income, maternal age and education.

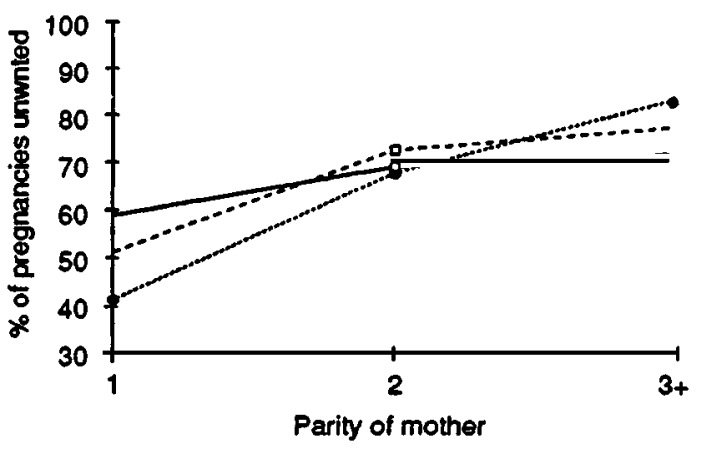

-0 Income s US\$ 50
$-\square$. Income US\$ 51-150
..- Income US\$151+

Fig. 2. Proportion of first pregnancies subsequent to a birth in 1982 that were reported by the mother as unwanted, according to family income and parity.

\section{DISCUSSION}

This study provided a rare opportunity to study fertility patterns in a developing country through prospective follow-up of women. Strenuous efforts were made to trace the cohort children at each follow-up and a high proportion were located, despite the high rate of mobility 2,7 . Some bias has probably been incurred with respect to this particular analysis since data were not collected from mothers whose cohort child had died by the time of the interview. This group of mothers were more likely to come from low income families, have lower educational levels and higher parity then those mothers whose cohort child survived. It might be expected that these women would be more likely to have another ("replacement") pregnancy, thus the risks of subsequent pregnancies in these subgroups would be underestimated in this analysis. This group constituted only $5 \%$ of the cohort traced, however, and therefore the potential biases are unlikely to be substantial.

Fertility differentials with respect to socioeconomic status vary widely across countries and regions ${ }^{5}$. Although Pelotas is located in one of the wealthier areas of Brazil, wide social inequalitics still exist. Since over $99 \%$ of the births in the city during 1982 were enrolled in the study, women from all social classes were represented. Our finding of fertility varying according to maternal education, even after allowing for other related factors, is in keeping with other studies in Latin American countries.

The decreasing proportions of women having subsequent pregnancies as age increases is not unexpected. The U-shaped trend seen with parity, however, could be due to many factors including desired family size and access to sterilisation. 
This trend was even more evident after adjustment for other related variables (principally age). The mechanisms by which caesarean delivery of the cohort child is associated with subsequent pregnancies are not clear. It is possible that we were unable to detect all women who underwent a caesarean for sterilisation reasons.

Also possible, however, is a decision to delay or to avoid subsequent pregnancies, perhaps on medical advice or for fear of further surgery most women in Brazil nowadays follow one caesarean section with anotherd.

A high proportion of mothers stated that they had not wanted their next pregnancy. This was more common among older women and those of low income or low educational level. However, these latter two groups were the ones most likely to have another pregnancy. Cultural practices and access to contraceptive services may have contributed to this finding. In relation to parity, the proportion of women not wanting the subsequent pregnancy differed according to income group. Women of low income showed little variation by parity in their desire for the subsequent pregnancy, while those in the top income group showed marked dif ferences between parities. This finding seems to indicate that a majority of women of low socioeconomic status do not want (or do not conciously plan) further pregnancies, regardless of their parity. Women of higher socio-economic status, on the other hand, appear more likely to plan their second child than their third, their third than their fourth, and so on. Perhaps this is due to these women being more aware of the possibilities and mechanisms of planning their families.

We were unable to investigate here the relationship between inter-gestational interval and the study factors since the relevant data were not gathered. In addition though, many of the women who had not had a subsequent pregnancy by the time of the interview will probably had one afterwards. Thus analyses of inter-gestational interval over this relatively short follow-up time would have been seriously limited.

In summary, fertility patterns in different socio-demographic groups have been demonstrated. Results relating birthweight, feeding practices and mode of delivery of the cohort child to those of their subsequent sibling will be reported elsewhere.

HUTTLY, S. R. A. et al. Gravidezes subseqüentes: quem as tem e quem as quer? Observaçס̄es em um centro urbano da regiảo Sul do Brasil. Rev. Saúde públ., S. Paulo, 24: 212-6, 1990.

RESUMO: Em um estudo de coorte de base populacional, foram estudados todos 036.011 nascimentos hospitalares ocorridos na cidade de Pelotas, RS, em 1982. As parturientes foram entrevistadas logo após - parto, e 80\% delas foram novamente contactadas em suas residências no início de 1986, em média 43 meses mais tarde. Dessas mulheres, $39 \%$ haviam engravidado novamente. Esta proporçăo variou inversamente em relaçăo à idade materna, anos de escolaridade e renda familiar. Quanto à paridade, a proporção de gravidezes subsqüentes foi maior para primíparas e para multíparas. Mães cujos filhos nasceram através de cesareana também apresentaram menor fecundidade, mesmo após exclusão daquelas que, por ocasiāo da operaçāo cesárea, sofreram ligadura de trompas. Análise através de regressāo logística mostrou que esses fatores permaneceram significativamente associados à fecundidade mesmo após o ajuste estatístico para as demais variáveis. Das mães que engravidaram após $1982,60 \%$ informaram que nảo a desejaram. A proporção das gravidezes indesejadas foi mais elevada em mulheres de maior paridade, sendo esta tendência mais marcada em mulheres de familias de alta renda.

DESCRITORES: Fertilidade. Raridade

\section{REFERENCES}

1. BAKKETEIG, L. S. \& HOFFMAN, H. J. Perinatal mortality by birth order within cohorts based on sibship size. Brit. med. J., 2: 693-6, 1979.

2. BARROS, F. C.; VICTORA, C. G.; VAUGHAN, J. P. The Pelotas (Brazil) birth cohort study 1982-1987: strategies for following-up 6,000 children in a developing country. Paed. Perinat. Epidem., 1989 [In press].

3. BRASS, W. Methods for estimating fertility and mortality from limited and defective data. Chapel Hill. Laboratories for Population Studies, University oi North Carolina, 1975.

4. FAÚNDES, A. As cesáreas e as moditicaçōes nos níveis de fecundidade. In: Populaçäo e saúde; Anais do Seminário Latino-Americano. Campinas, Ed. UNICAMP, 1986. v. 1, p. 73-91.

5. FREEDMAN, F. Fertility determinants. In: Cleland, J. \& Scott, C. The world jertility survey: an assessment. Oxford, Clarendon Press, 1987.

6. LUNDE, A. S. The birth number concept and record linkage. Amer. J. publ. Hlth, 65: 1165-9, 1975.

7. VICTORA, C. G.; BARROS, F. C.; VAUGHAN, J. P. Epidemiologia de desigualdade: um estudo longitudinal de 6.000 crianças brasileiras. São Paulo, Ed. Hueitec, 1988.

Recebido para publicaçăo em 30/10/1989 Aprovado para publicação em 23/1/1990 